EPRA International Journal of Economic and Business Review-Peer Reviewed Journal Volume - 8, Issue -12, December 2020 |e-ISSN: 2347 - 9671| p- ISSN: 2349 - 0187 SJIF Impact Factor (2020): 8.107|| ISI Value: 1.433|| Journal DOI URL: https://doi.org/10.36713/epra2012

\title{
STUDY OF IMPACT OF AIR POLLUTION ON PLANTS BY ESTIMATION OF APTI OF CERTAIN TREES IN KATRAJ AREA IN PUNE CITY
}

\begin{tabular}{|c|c|}
\hline Erum F H Kazi & $\begin{array}{c}\text { Asst- Professor, Department of Environmental } \\
\text { Science, Abeda Inamdar Senior College, Pune, } \\
\text { India. }\end{array}$ \\
\hline Dr. Satish Kulkarni & $\begin{array}{c}\text { Associate Professor, HOD, New Arts Commerce and } \\
\text { Science College, Ahmednagar, Maharashtra }\end{array}$ \\
\hline
\end{tabular}

\section{ABSTRACT}

Article DOI URL: https://doi.org/10.36713/epra6014

Air pollution is one of major concerns in Pune City currently. Study highlights increase in Particulate matter from Vehicular sources \& Urbanization in Karaj area is having harmful impact on the trees in the area.

Leaf of Plant species such as Peepal( Ficusreligiosa),, Tamarind(Tamarindusindica), Rain tree( Samaneasaman), Ashoka ( Saracaasoca), Manago( Mangiferaindica), Almond( Terminaliacatappa), Banyan tree(Ficusbenghalensis) were selected and it was found that Ashoka( Saracaasoca), Mango tree( Mangiferaindica) showed Intermediate APTI whereas Peepal, Tamarind, Rain tree, Almond, Banyan tree were found to be Sensitive to pollution.

KEYWORDS: Air Pollutants, APTI of plants, Total Chlorophyll, Ascorbic acid, $p$ H of leaf, Relative water Content $(\boldsymbol{R W C})$

\section{INTRODUCTION}

Air Pollution is turned out to be major problem in Pune city. Increased air pollution is attributed to developmental activities, Urbanization \& increased number of vehicles in Pune city. These air pollutants are having major impacts on the plants and trees. Plants susceptibility and tolerance towards air pollution can be determined by calculating APTI of plants using parameters like -Total Chlorophyll, Relative water content( RWC), Ascorbic acid content and $\mathrm{p} \mathrm{H}$ of plant.

\section{MATERIALS AND METHODS}

Study area

Katraj area was selected as study area which is located in Pune city. Located in $18^{\circ} 27^{\prime} 13^{\prime} \mathrm{N}$ and 7351'42"E.Leaf samples were collected from Katraj Bus stop and surrounding area, and APTI calculations were done. The plant species selected for the area are as follows- Almond ( Terminaliacatappa) ,Ashoka (Saracaasoca), Mango ( Mangiferaindica), Peepal( Ficusreligiosa), Rain tree ( Samaneasaman), Tamarind (Tamarindusindica), Banyan tree (Ficusbenghalensis). 
Samples were collected in triplicates in month of January 2018.

1. Total Chlorophyll Estimation- was done by method of Arnon

2. Relative water content was determined by taking Initial and Final weight of plant sample by drying it in Hot air Oven

3. $\mathrm{pH}$ of plant sample was determined by using calibrated $\mathrm{pH}$ meter

4. Ascorbic acid content of plant sample was done using method of Sadasivam and Manikam

APTI (Air Pollution Tolerance Index) was calculated using formula -
Air pollution tolerance Index of species $=[\mathrm{A}(\mathrm{T}+\mathrm{P})]$

$+\mathrm{R} / 10$

Where

$\mathrm{A}=$ ascorbic acid content of leaf in $\mathrm{mg} / \mathrm{g}$ dry weight

$\mathrm{T}=$ total chlorophyll content of leaf in $\mathrm{mg} / \mathrm{g}$ dry weight

$\mathrm{P}=$ Leaf extract $\mathrm{pH}$

$\mathrm{R}=$ Relative water content $(\mathrm{RWC})$

$10=$ Total sum is divided by 10 to obtain APTI values

After calculations result was interpreted asplants showing APTI between 30-100 were termed as Tolerant, APTI between - 29-17 were termed as Intermediate and plants having APTI between 16-1 were termed as Sensitive to Air Pollution.

\section{RESULTS AND DISCUSSION}

Table 1-Showing Air Pollution data for January 2019 - Data Source- IITM, Pashan

\begin{tabular}{|c|c|c|c|c|}
\hline Month & $\begin{array}{c}\text { PM 10 } \\
\text { (Particulat } \\
\text { e matter } \\
\text { ) } \mu \mathrm{g} / \mathrm{m}^{3}\end{array}$ & $\begin{array}{c}\text { PM 2.5 } \\
\text { (Particulate matter }) \mu \mathrm{g} / \mathrm{m}^{3}\end{array}$ & NO $_{\mathrm{x}}$ & SO $_{\mathrm{x}}$ \\
\hline January 2018 & 297.5 & 144.3 & 38.2 & 35 \\
\hline
\end{tabular}

It was found that PM 10 (Particulate matter) and PM 2.5 (Particulate matter) are major air pollutants in Katraj area beyond permissible limit .These pollutants are due to vehicles and Urbanization. These pollutants are having major impact on the plants in Katraj area.

Changes in all 4 parameters were observed. High Relative Water content in plants is an indicator that plants are tolerant to air pollution. High Total chlorophyll Content is an indicator that plants are not affected by air pollution. Plants having high Ascorbic acid content were found to be tolerant to air pollution. Plants showing $\mathrm{pH}$ below 7 are susceptible to air pollution and plants above 7 are tolerant towards air pollution.

Table -2

Results showing APTI ( Air Pollution Tolerance Index) of Katraj area near Bus stop and surrounding area

\begin{tabular}{|c|c|c|c|c|c|c|c|}
\hline Parameters & Peepal & Tamarind & Rain tree & Ashoka & Mango & Almond & Banyan \\
\hline p H & 2.3 & 2 & 2.3 & 3.1 & 3.6 & 1.9 & 3.6 \\
\hline $\begin{array}{c}\text { Relative } \\
\text { water } \\
\text { content }\end{array}$ & 0.066 & 0.078 & 0.112 & 0.094 & 0.142 & 0.024 & 0.085 \\
\hline $\begin{array}{c}\text { Total } \\
\text { Chlorophyll }\end{array}$ & 0.025 & 0.029 & 0.0252 & 0.0261 & 0.024 & 0.029 & 0.028 \\
\hline $\begin{array}{c}\text { Ascorbic acid } \\
\text { APTI }\end{array}$ & 66.4 & 66.4 & 49.8 & 66.4 & 66.4 & 66.4 & 33.2 \\
\hline Sensitive & Sensitive & Sensitive & Intermediate & Intermediate & Sensitive & Sensitive \\
\hline
\end{tabular}




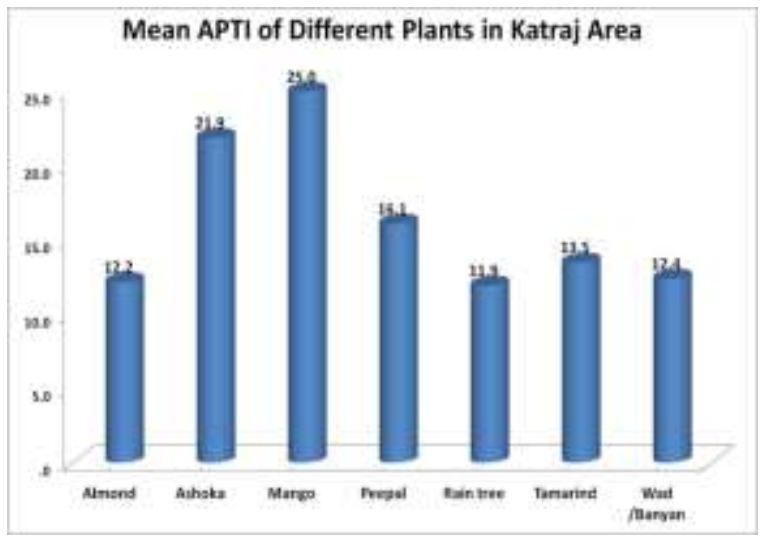

It is found that Mango tree showed highest APTI , followed by Ashoka tree, Peepal tree , Tamarind tree, Banyan tree and Rain tree. Highest
APTI shows tolerance towards air pollution and lowest APTI shows sensitivity towards air pollution.

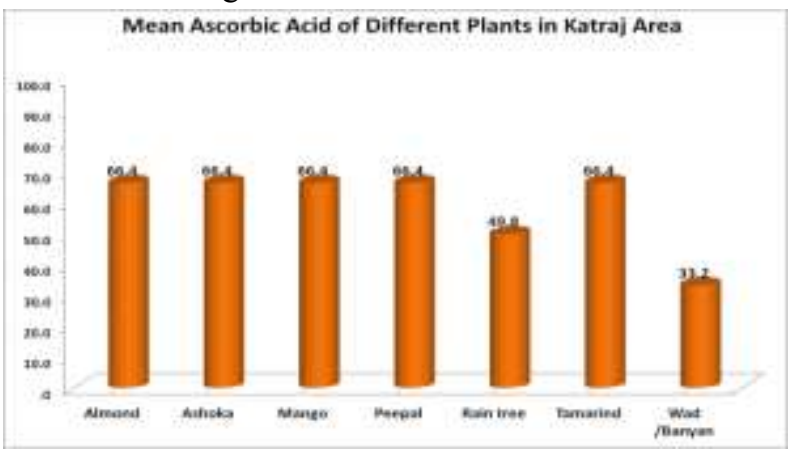

It was found that highest Ascorbic acid content was seen in Almond, Ashoka, Mango, Peepal,
Tamarind tree and lowest in Rain tree. More Ascorbic acid content more tolerant is plant to air pollution

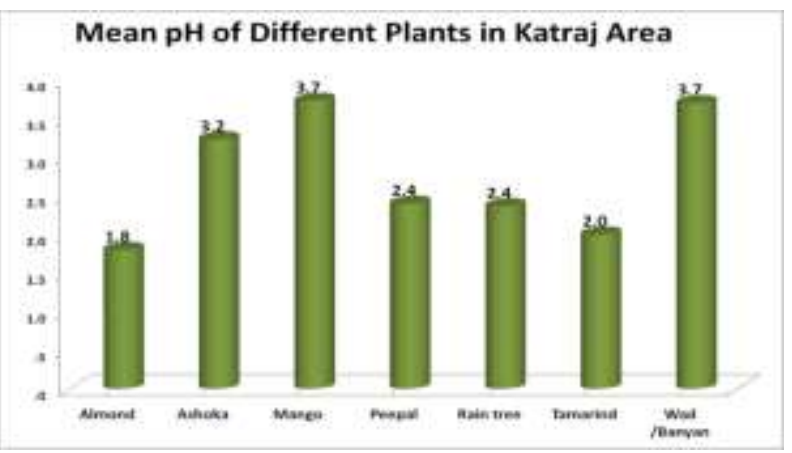

$\mathrm{P} \mathrm{H}$ was found to be mostly acidic due to presence of air pollutants. Mango , Banyan tree showed $\mathrm{p} \mathrm{H}$ towards acidic, lowest was seen in
Almond tree. Low $\mathrm{p} \mathrm{H}$ levels indicate sensitivity and intolerance of plants towards air pollution. 


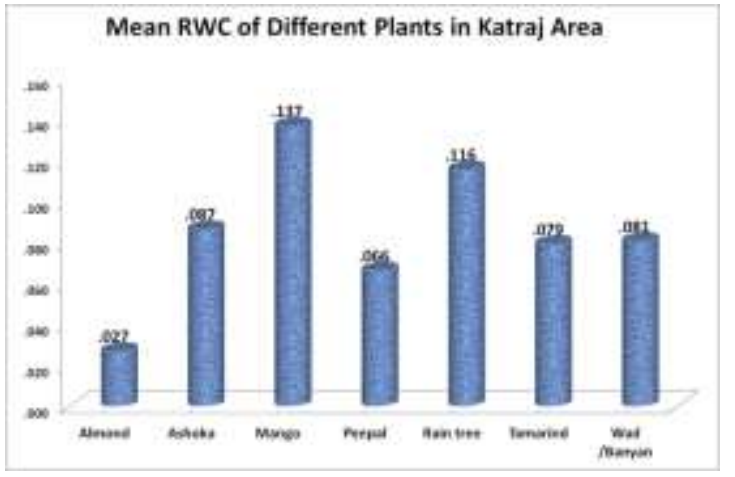

Highest relative water content was seen in Mango tree and lowest in Almond tree. Low Relative

water content indicates that the plants are impacted because of pollution.

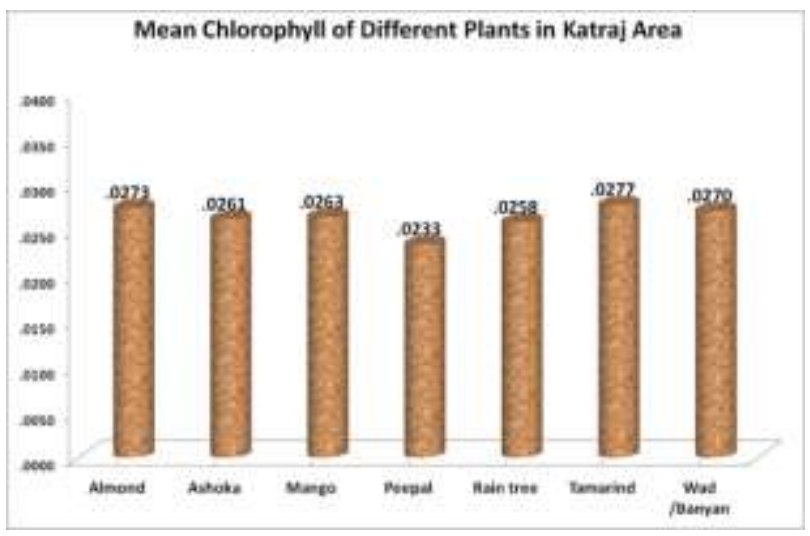

It was found that all plants showed low chlorophyll content because of impact of pollution on plants . Lohegaon area was selected for the study. Samples were collected from Airport to find out impact of air pollution on plants in Lohegaon area .

\section{RESULTS \& DISCUSSION}

Ascorbic acid Content was found to be highest in Almond, Ashoka, Mango, Peepal, Tamarind trees, followed by Rain tree and lowest in Banyan tree. $\mathrm{p} \mathrm{H}$ was found to be lowest in all the plants showing impact of pollution on them. Almond tree showed lowest $\mathrm{p} \mathrm{H}$. Relative Water Content (RWC) was found to be Highest in Mango tree and Rain tree . Lowest Relative water content (RWC) was observed in Almond tree. Chlorophyll content was found to be nearly same in all plants.

APTI showed that onlyAshoka and Mango tree are Intermediate to pollution whereas Peepal, Tamarind, Rain tree and Banyan tree are sensitive to Air pollutant.

\section{CONCLUSION}

APTI (Air Pollution Tolerance Index of plants can be used as indicator of plants that can be used to control air pollution in Katraj area. It can be concluded that Asoka and Mango tree can be planted to reduce the effect of Air Pollution. Particulate matter in Karaj area can be reduced by vehicle maintenance, use of ecofriendly fuel and Plantation of trees.

\section{Acknowledgement-}

I would like to thank Dr. Gufran Baig, Director IITM (Indian Institute of Tropical Meteorology), my Parents, Brother and Miss Jannat Kazmi(Friend) for their support and guidance during my research work.

\section{BIBLIOGRAPHY}

1. Aceves-Fernandez, M. A., Pedraza-Ortega, J. C., Sotomayor-Olmedo, A., Ramos-Arreguín, J. M., Vargas-Soto, J. E., \& Tovar-Arriaga, S. (2012). Analysis of Key Features of Non-Linear Behavior Using Recurrence Plots. Case Study: Urban Pollution at Mexico City. Journal of Environmental Protection, 3(29), 1147-1160.

2. Augustine, C. (n.d.-a).Impact of air pollution on the environment in Port Harcourt, Nigeria. Retrieved from http:// www.wudpeckerresearchjournals.org/JESWR/P $\mathrm{df} / 2012 /$ A pril/ Augustine.pdf

3. Augustine, C. (n.d.-b). Impact of air pollution on the environment in Port Harcourt, Nigeria. Retrieved from http:// www. wudpeckerresearchjournals.org/JESWR/P df/2012/A pril/ Augustine.pdf

4. Barman, S. C., Kumar, N., Singh, R., Kisku, G. C., Khan, A. H., Kidwai, M. M., ... Verma, A. K. (2010). Assessment of urban air pollution and it's probable 
health impact. Journal of Environmental Biology, 31(6), 913-920.

5. Begum, B. A., Biswas, S. K., Markwitz, A., \&Hopke, P. K. (2010).Identification of sources of fine and coarse particulate matter in Dhaka, Bangladesh.Aerosol Air Qual. Res, 10, 345-353.

6. Brunekreef, B., \& Holgate, S. T. (2002).Air pollution and health.Lancet, 360, 1233-1242.

7. Chattopadhyay, S., Gupta, S., \&Saha, R. N. (2010). Spatial and Temporal Variation of Urban Air Q uality: A GIS Approach. Journal of Environmental Protection, 1(3), 264-277.

8. Chouhan A, Sanjeeda I, Maheshwari RS, Bafna A. Study of air pollution tolerance index of plants growing Pithampur Industrial area sector 1, 2 and 3. Research Journal of Recent Sciences.2012; 1:172-177.

9. Davidson, C. I., Phalen, R. F., \& Solomon, P. A. (2005). Airborne particulate matter and human health: A review. Aerosol Science and Technology, 39(8), 737-749.

10. Dubey, N., \& Pervez, S. (2008). Investigation of Variation in Ambient PM10 Levels within an UrbanIndustrial Environment.Aerosol Air Qual. Res, 8, 5464.

11. Ediagbonya, T. F., Tobin, A. E., \&Ukpebor, E. E. (2013). The level of suspended particulate matter in wood industry (sawmills) in Benin City, Nigeria. Journal of Environmental Chemistry and Ecotoxicology Vol, 5(1), 1-6.

12. ElAssouli, S. M. (2011). Airborne particulate matter (PM10) composition and its genotoxicity at two pilgrimage sites in Makkah, Saudi Arabia.journal of Environmental Chemistry and Ecotoxicology Vol, 3(4), 93-102.

13. Fujita, E. M., Croes, B. E., Bennett, C. L., Lawson, D. R., Lurmann, F. W., \& Main, H. H. (1992). Comparison of emission inventory and ambient concentration ratios of $\mathrm{CO}, \mathrm{NMOG}$, and $\mathrm{NOX}$ in California's South Coast Air Basin.Journal of the Air $\&$ Waste Management Association, 42(3), 264-276.

14. Hao, J., \& Wang, L. (2005).Improving urban air quality in China: Beijing case study.Journal of the Air $\&$ Waste Management Association, 55(9), 1298-1305.

15. Horaginamani, S. M., \&Ravichandran, M. (2010a). Ambient air quality in an urban area and its effects on plants and human beings: a case study of Tiruchirappalli, India. Kathmandu University Journal of Science, Engineering and Technology, 6(2), 13-19.

16. Horaginamani, S. M., \&Ravichandran, M. (2010b). Ambient air quality in an urban area and its effects on plants and human beings: a case study of Tiruchirappalli, India. Kathmandu University Journal of Science, Engineering and Technology, 6(2), 13-19.

17. Horaginamani, S. M., \&Ravichandran, M. (2010c). Ambient air quality in an urban area and its effects on plants and human beings: a case study of Tiruchirappalli, India. Kathmandu University Journal of Science, Engineering and Technology, 6(2), 13-19.

18. Iqbal, M. Z., \&Shafig, M. (2001).Periodical effect of cement dust pollution on the growth of some plant species.Turk. J. Bot, 25, 19-24.

19. Jovalvsević-Stojanović, M., \&Bartonova, A. (2010a).Current state of particulate matter research and management in Serbia.Chemical Industry and Chemical Engineering Quarterly, 16(3), 207-212.

20. Jovalvsević-Stojanović, M., \&Bartonova, A (2010b).Current state of particulate matter research and management in Serbia.Chemical Industry and Chemical Engineering Quarterly, 16(3), 207-212.

21. Jyothi, S. J., \& Jaya, D. S. (2010).Evaluation of air pollution tolerance index of selected plant species along roadsides in Thiruvananthapuram, Kerala.J. Environ. Biol, 31, 379-386.

22. Kathuria, V. (2005).Vehicular Pollution ControlConcept note.Madras School of Economics, Gandhi Mandapam Road, Chennai, 600, 025. 